\title{
On the transpiration of wild olives under water-limited conditions in a heterogeneous ecosystem with shallow soil over fractured rock
}

\author{
Roberto Corona*, Nicola Montaldo \\ Dipartimento di Ingegneria Civile Ambientale e Architettura, Università di Cagliari, Via Marengo, 3, I-09123 Cagliari, Italy. \\ * Corresponding author. Tel.: +39-070-675-5318. E-mail: roberto.corona@unica.it
}

\begin{abstract}
Mediterranean ecosystems are typically heterogeneous and savanna-like, with trees and grass competing for water use. By measuring sap flow, we estimated high transpiration of wild olive, a common Mediterranean tree, in Sardinia despite dry conditions. This estimate agrees with independent estimates of tree transpiration based on energy balance, highlighting the wild olive's strong tolerance of dry conditions. The wild olive can develop an adaptation strategy to tolerate dry conditions. In this Sardinian case study, the wild olive grew in shallow soil, and the tree roots expanded into the underlying fractured basalt. The trees survived in dry periods using water infiltrated during wet seasons into fractured rocks and held in soil pockets. We estimated a high upward vertical flux through the bottom soil layer from the underlying substrate, which reached 97\% evapotranspiration in August 2011. The water taken up by tree roots from bedrock hollows is usually neglected in ecohydrological modeling.
\end{abstract}

Keywords: Evapotranspiration; Rock moisture; Water uptake; Sap flow; Energy balance.

\section{INTRODUCTION}

In the Mediterranean regions there is a persistent declining trend in precipitation and decreasing runoff (Altin and Barak, 2014; Martinez-Fernandez et al., 2013; Montaldo and Sarigu, 2017; Vicente-Serrano et al., 2011), with consequences for the sustainability of agricultural and water resources. Mediterranean ecosystems are typically heterogeneous and savanna-like, with contrasting plant functional types (e.g., trees and grass) competing for water use (Breshears, 2006; Detto et al., 2006; Montaldo et al., 2008; Sankaran et al., 2005; Scholes and Archer 1997; Villegas et al., 2014). In these ecosystems, evapotranspiration $(E T)$ is a leading loss term of the root-zone water budget (Rana and Katerji, 2000), which may reach a yearly magnitude roughly equal to precipitation in semi-arid conditions (Baldocchi et al., 2004; Kurc and Small, 2004; Maselli et al., 2004; Reynolds et al., 2000; Rodriguez-Iturbe, 2000). Despite the attention these ecosystems have received (Breshears, 2006; Holdo and Brocato, 2015; Yu and D'Odorico, 2015), a general lack of knowledge persists about how to partition ET into its components (Eliades et al., 2018; Williams et al., 2004; Zhou et al., 2016), and about the relationship between ET and plant survival strategies under water stress.

Detto et al. (2006) investigated a typical heterogenous Mediterranean ecosystem in water-limited conditions located at Orroli in Sardinia (Italy), a site with a patchy mixture of Mediterranean vegetation types: trees (mainly wild olive, Olea sylvestris) and grass on thin soil $(\sim 17 \mathrm{~cm}$ depth) above fractured basalt (Montaldo et al., 2008; Montaldo et al., 2013). Using an eddy covariance tower to estimate $E T\left(E T_{E C}\right)$, Detto et al. (2006) highlighted a strong tolerance to prolonged drought of the wild olive, a common Mediterranean species (Lumaret and Ouazzani, 2001; Terral et al., 2004), which still, even during the extreme dry conditions of summer 2003, transpired at rates close to potential.

Nowadays, ET is widely estimated using eddy covariance towers (Detto et al., 2006; Jung et al., 2010; Williams et al., 2012), but direct measurements are required for estimating the tree transpiration component $\left(T_{t}\right)$ in heterogenous ecosystems and dry conditions. Indeed, as soil dries, the mean ecosystem $E T$ becomes low and the $T_{t}$ component becomes predominant, especially with low tree cover (e.g., $<40 \%$ of the mosaic), as is typical in these ecosystems (Baldocchi et al., 2004; Detto et al., 2006; Kurc and Small, 2004; Montaldo et al., 2008). In this sense, the use of sap flow sensors to estimate tree transpiration (Oren et al., 1998) is very attractive (Bovard et al., 2005; Cammalleri et al., 2013; Hassler et al., 2018; Liu et al., 2015; Montaldo et al., 2020; Oishi et al., 2008; Paço et al., 2009; Williams et al., 2004). At the same time, sap flux measurements may themselves be affected by errors associated with calibration (Köstner et al., 1998; Steppe et al., 2015). Estimating $T_{t}$ reliability is essential for identifying the likely source of water during the dry season, and so independent verification of this value would decrease the uncertainty. We propose to make such verification using an approach based on energy balance (Detto et al., 2006; Fritschen and Simpson, 1989; Garratt, 1992). We recognize that the energy balance approach is also somewhat uncertain (Foken, 2008), but if two very different approaches produce a similar estimate of $T_{t}$, then results from subsequent analyses become more reliable.

Sap flow sensors are already used for estimating $T_{t}$ in cultivated (both rainfed and irrigated) olive trees (Olea europaea) (Chebbi et al., 2018; Karray et al., 2008; Rallo and Provenzano, 2013; Tognetti et al., 2004). As expected, $T_{t}$ decreased drastically as soil dried in rainfed cultivated olive trees, reaching very low values (Ennajeh et al., 2008; Sofo et al., 2008); this is also commonly represented in ecohydrologic models (Karray et al., 2008; Kutílek and Nielsen, 1994; Laio et al., 2001; Nadezhdina et al., 2015; Rallo and Provenzano, 2013; Verhoef and Egea, 2014). We used sap flow sensors for $T_{t}$ measurements of the Sardinian wild olive trees (Montaldo et al., 2020), and investigated its relationship with soil moisture; this relationship should be almost invariant according to Detto et al. (2006), in contrast with the observations in rainfed cultivated olives noted above.

According to field experiments in the Mediterranean region for other tree species, such as holm oaks in Portugal (Balugani et al., 2017; David et al., 2007; Paço et al., 2009), Spain (Perez- 
Priego et al., 2017), and southern France (Limousin et al., 2009), trees also transpired at relatively high rates during dry summers. However, these sites were characterized by deep soils or shallow groundwater (Balugani et al., 2017), while the Sardinian trees that Detto et al. (2006) investigated grew in shallow soil. Generally, the behavior of ET components during periods of water stress depends on soil depth. In deep soils, transpiration and evaporation are theoretically expected to draw from distinct water sources, with evaporation decreasing as surface water decreases; tree transpiration remains high because roots uptake water from deep soil layers. In thin soils with shallow-rooted plants, evaporation and tree transpiration are theoretically expected to utilize the same surface water source, both becoming negligible when the soil dries entirely (Berkelhammer et al., 2016). Although the Sardinian field site should be an example of the second case, the thin soil in Sardinia sits above fractured bedrock (Detto et al., 2006), which is quite common in semi-arid and arid climates (Schwinning, 2010). For instance, in Mediterranean regions, upstream watersheds are often characterized by trees growing on such shallow soils above fractured bedrock or cemented horizons (Witty et al., 2003). In these conditions, roots may penetrate below the thin soil through cracks, fractures, and dissolution features, and trees can survive dry seasons using water infiltrated during previous wet seasons into fractured rocks and held in soil pockets (Cannon, 1911; Eliades et al., 2018; Estrada-Medina et al., 2013). This water becomes a sort of "rock moisture" (Rempe and Dietrich, 2018). Water uptake by roots in the rocks may be predominant for $E T$, up to $70-90 \%$ in semi-arid and arid climates (Breshears et al., 2009; Eliades et al., 2018; McCole and Stern, 2007; Schwinning, 2010). This is a significant water source of ET that ecohydrologists usually neglect (Schwinning, 2010). The water uptake of roots in the rocks may be the actual source of the wild olive's transpiration under dry conditions in the Sardinian field.

We thus had the following objectives: 1) to quantify wild olive transpiration and its relationship with soil moisture, evaluating tree resistance to dry conditions; and 2) to quantify the eventual water uptake of the tree roots from the rocks and its role in sustaining the survival of wild olive during dry periods.

\section{METHODS}

\section{The Orroli site}

The Orroli field site is located in east-central Sardinia $\left(39^{\circ} 41^{\prime} 12.57^{\prime \prime} \mathrm{N}, 9^{\circ} 16^{\prime} 30.34^{\prime \prime} \mathrm{E}, 500 \mathrm{~m}\right.$ a.s.l.; see details in Detto et al., 2006; Detto et al., 2008; Montaldo et al., 2008; Montaldo et al., 2013). The landscape is a patchy mixture of tree clumps forming canopy cover over $\sim 33 \%$ of the footprint area, $\sim 1.5 \mathrm{~km}^{2}$ on a gently sloping $\left(\sim 3^{\circ}\right.$ from northwest to southeast) plateau, and inter-clump zones are covered by herbaceous and grass species during periods of high moisture. The dominant tree species is wild olive, in patches ranging in height from 3.5-4.5 m, and C3 herbaceous (grass) species (Asphodelus microcarpus, Ferula comunis, Bellium bellidioides, Scolymus hispanicum, Sonchus arvensis, Vicia sativa, Euphorbia characias, Daucus carota, Bellis perennis; monocotyledons: Avena fatua, Hordeum murinum) grow only during wet seasons, reaching approximate heights of $0.5 \mathrm{~m}$ (Montaldo et al., 2008; Montaldo et al., 2013).

The climate at the flux site is maritime Mediterranean, with a mean annual precipitation (1922-2007) of $643 \mathrm{~mm}$; mean monthly precipitation varies from $93 \mathrm{~mm}$ in December to 11 $\mathrm{mm}$ in July. The mean annual air temperature is $14.6^{\circ} \mathrm{C}$, with mean monthly values ranging between $23.7^{\circ} \mathrm{C}$ in July and $7.1^{\circ} \mathrm{C}$ in January. The soil ranges in depth from $0-50 \mathrm{~cm}$, averaging $17 \mathrm{~cm} \pm 6 \mathrm{~cm}$ (standard deviation, SD) above fractured basalt; quickly plunging into water-limited conditions during the rainless summer (Detto et al., 2006; Montaldo et al., 2008). The soil is silt loam ( $19 \%$ sand, $76 \%$ silt, $5 \%$ clay) with a bulk density of $1.38 \mathrm{~g} / \mathrm{cm}^{3}$ and porosity of 53\%. In May 2017 electrical resistivity tomography (ERT) was used to detect singularities such as cracks, fractures and soil pockets in the rocks, and their relative water content (Muchingami et al., 2012; Nijland et al., 2010; Rodriguez-Robles et al., 2017; Travelletti et al., 2012). The $23.5 \mathrm{~m}$ long images (unit electrode spacing of $0.50 \mathrm{~m}$ ) were collected along three transects at $2 \mathrm{~m}$, $5 \mathrm{~m}$ and $8 \mathrm{~m}$ from a tree clump. Rocks, cracks, soil pockets and water content were qualitatively estimated from the observed electrical resistivity map of each transect. Tree roots penetrating vertically into the fractured basalt were also noted when digging root trenches and other excavations for a separate study.

\section{Micrometeorogical and soil measurements}

Three-dimensional time series data for wind velocity, air temperature, and $\mathrm{CO}_{2}$ and water vapor gas concentration at 10 $\mathrm{Hz}$, were averaged over 30-minute intervals (Montaldo et al., 2008; Montaldo et al., 2013; Montaldo and Oren, 2016). This data was used to estimate ET and sensible heat flux based on the standard eddy covariance method (Baldocchi, 2003). The measurements were made with a Campbell Scientific CSAT-3 tri-axial sonic anemometer (Campbell Scientific Inc., Logan, Utah, USA) and a Licor-7500 $\mathrm{CO}_{2} / \mathrm{H}_{2} \mathrm{O}$ infrared gas analyzer (Licor Inc., Lincoln, NE, USA) positioned adjacent to each other at the top of a $10 \mathrm{~m}$ tall tower, operating from April 2003 at the Orroli site (Detto et al., 2006). The effect of the gentle slope of the plateau was removed by utilizing the conventional planar fit method, and the Webb-Pearman-Leuning adjustment was applied (Detto et al., 2006; Detto et al., 2008).

A Vaisala HMP45 (Vaisala, Helsinki, Finland) sensor was used to measure air temperature $\left(\xi_{a}\right)$ and relative humidity $(R H)$. Vapor pressure deficit, $V P D$, was calculated as $V P D=$ $e^{*}\left(\xi_{a}\right)(1-R H)$, where the saturation vapor pressure $e^{*}$ is related to $\xi_{a}$ through the Clausius-Clayperon equation (Stull, 1988).

Three infrared transducers, IRTS-P (Apogee Instrument Inc., Logan, Utah, USA) (accuracy of $0.3^{\circ} \mathrm{C}$ ), were used to measure the surface temperature $\left(\xi_{s}\right)$ of the different land cover components. One IRTS-P was positioned to monitor the leaf surface temperature of a wild olive canopy clump at $3.5 \mathrm{~m}$ height above the ground with a canopy view zenith angle of $\sim 70^{\circ}$, a second sensor was positioned to monitor either bare soil or grass (depending on the season) at $1.6 \mathrm{~m}$ above the ground with a view zenith angle of $\sim 50^{\circ}$, and a third sensor was placed at a greater height $\left(10 \mathrm{~m}\right.$ above the ground, view zenith angle of $\left.\sim 40^{\circ}\right)$ to observe a mixture of trees and bare soil or grass. To derive net radiation, the incoming and outgoing shortwave and longwave radiation components were measured with a CNR-1 (Kipp and Zonen, Delft, The Netherlands) integral radiometer positioned at $10 \mathrm{~m}$ with a hemispherical field of view. Photosynthetically active radiation $(P A R)$ was measured with a LI-190 Quantum Sensor (Licor Inc., Lincoln, NE, USA). Soil heat flux was measured at two locations close to the tower with thermopile plates, HFT3 (REBS), placed $8 \mathrm{~cm}$ below the surface, and two thermocouples (per plate) were placed at 2 and $6 \mathrm{~cm}$ to estimate soil temperature.

Seven frequency domain reflectometer probes (FDR, Model CS-616, Campbell Scientific Inc., Logan, Utah, USA) were inserted in the soil close to the tower (3.3-5.5 m away) to 
estimate mean soil moisture $(\theta)$ within the soil layer. FDR calibration $\left(\theta=2.456-7.135 \tau+6.701 \tau^{2}-1.884 \tau^{3}\right.$, where $\tau$ is the output period in milliseconds) was made using 15 periodic gravimetric water content samples taken over a wide range of $\theta$ (0.08-0.52) near the probes.

Precipitation was measured using a PMB2 rain gauge (CAE, San Lazzaro di Savena, Italy). To estimate the fraction of land cover components at the site, a multispectral, high-spatialresolution $(2.8 \mathrm{~m})$ Quickbird satellite image (DigitalGlobe Inc.) was acquired (3 August 2003) (Detto et al., 2006), and we applied a supervised classification scheme based on the parallelepiped algorithm (Montaldo et al., 2008). This classification was verified using more recent Google Earth images (12 December 2010 and 17 March 2017).

\section{Sap flow measurements}

We used four sap flow sensors of the SFS2 M type (UP $\mathrm{GmbH}$, Ibbenbüren, Germany), which comprise two needles with copper-constantan thermocouples and a heating wire. The top needle was heated using a constant power source of 120 $\mathrm{mA}$. Both thermocouples were interconnected and provided a signal that corresponds directly with the temperature difference of both sensor elements. The temperature difference was influenced by the sap flow density (Granier, 1987), and the mean value of xylem water flux $\left(j_{s}\right)$ along the radius is expressed as (Granier, 1985):

$j_{s}=0.714\left[\left(\Delta t_{\text {night }} / \Delta t_{\text {actual }}\right)-1\right]^{1.231}$

where $\Delta t_{\text {night }}$ is the temperature difference at night (i.e., when sap flow is zero), and $\Delta t_{\text {actual }}$ is the actual temperature difference.

The sensors (length of $2 \mathrm{~cm}$ ) were inserted into the trunks of four wild olive trees at a height of $40 \mathrm{~cm}$. The diameters of the wild olive trees ranged from $6.8 \mathrm{~cm}$ to $8.3 \mathrm{~cm}$, and the monitored trees were in a clump (at $3 \mathrm{~m}$ from the tower) that was also monitored by one infrared transducer. Measurements were taken from the sensors at $1 \mathrm{~s}$ intervals, averaged over $30 \mathrm{~min}$, and stored on a CR3000 datalogger (Campbell Scientific, Logan, UT, USA). Sap flux was measured from August 30, 2011, to December 30, 2011, hereinafter called the "SF-period" (DOY $=243-364,2011)$. We also used the recent (from August 22, 2014 to July 9, 2017) sap flux measurements of Montaldo et al. (2020) to increase the data extension.

\section{Transpiration estimate at tree scale}

Tree transpiration was first estimated using the sap flow sensors. The mean value of tree sap flows, $\overline{J_{s}}$, was scaled to tree transpiration, $T_{t}^{S F}$, using $A_{s w} / A_{g}$ ( $A_{s w}$ is the tree sapwood area, and $A_{g}$ is the ground area of the clump canopy projection) as (Oren et al., 1998):

$$
T_{t}^{S F}=\overline{J_{S}} \frac{A_{s w}}{A_{g}}
$$

$A_{s w}$ was estimated at an average $41.3 \mathrm{~cm}^{2}$ from sapwood depth measurements made in the cores of three trees in the clump, and $A_{s w} / A_{g}$ averaged 0.0031 .

For the energy balance-based tree transpiration estimate, $T_{t}^{E B}$, we followed the approach of Detto et al. (2006), using their Equations (7)-(14), which use tree canopy $\xi_{\text {s, }}$, wind velocity, air temperature, and radiometer measurements.

We also estimated the tree $\beta$-function (Detto et al., 2006; Verhoef and Egea, 2014):
$\beta=\frac{T_{t}}{P E}$

where $T_{t}$ is the tree transpiration, and $P E$ is the potential evaporation which was estimated using the Priestley-Taylor equation [e.g., Brutsaert (1992), Equation (10.23)], with the $\alpha_{e}$ PriestleyTaylor coefficient assumed to be equal to 1.26.

\section{Evapotranspiration estimate at the scale of the eddy covariance footprint}

Evapotranspiration was estimated using the eddy-covariance method $\left(E T_{E C}\right)$, which provides an $E T$ estimate related to the flux footprint of the micrometeorological tower.

Upscaling the sap-flux measurements to the eddy covariance footprint was accomplished by multiplying $T_{t}^{S F}$ by the fraction of tree cover in the footprint, $F_{f p, t}$, thereby assuming that the monitored wild olives and their transpiration were representative of the trees in the eddy covariance footprint. $F_{f p, t}$ was estimated using the high-resolution satellite image and applying the twodimensional footprint model of Detto et al. (2006) (Equation (4)).

A total evapotranspiration at the eddy-covariance footprint scale $\left(E T_{f p}\right)$ was also estimated as:

$E T_{f p}=F_{f p, t} T_{t}+F_{f p, g} T_{g}+F_{f p, b s} E_{b s}+E_{w}$

where $E_{b s}$ is the soil evaporation, $T_{g}$ is the grass transpiration, and $F_{f p, g}$, and $F_{f p, b s}$ are the fractions of grass cover and bare soil in the flux footprintrespectively, estimated using Equation (4) of Detto et al. (2006), with $F_{f p, t}+F_{f p, g}+F_{f p, b s}=1$. We estimated $T_{g}$ and $E_{b s}$ using the energy balance method, Equations (7)-(14) of Detto et al. (2006), which takes surface temperatures $\left(\xi_{s}\right)$, wind velocity, air temperature, and radiometer measurements. The $E T_{f p}$ estimate can be compared with the eddy covariancebased estimate of $E T\left(E T_{E C}\right)$.

\section{Soil water balance to estimate the water uptake of the tree roots in the rock}

The soil water balance at the scale of the eddy covariance footprint can be estimated as:

$P-Q-E T-f_{d}=\Delta S$

where $P$ is the precipitation, $\Delta S$ is the variation of water in the soil layer, $f_{d}$ is the vertical flux through the bottom of the soil layer from the underlying rocky substrate, and $Q$ is runoff. $Q$ is typically a large loss term during wet periods (Corona et al., 2018; Montaldo and Sarigu, 2017), and decreases in the dry season. During wet periods dominated by drainage, $f_{d}$ is commonly downward (positive), but it may become upward (negative) during dry periods, when root water uptake may sustain wild olive transpiration. Soil water budget terms were computed on a monthly time scale, which is appropriate for deep soil water dynamics (e.g., Miller et al., 2010; Orellana et al., 2012).

In order to estimate $f_{d}$ from the soil water balance Equation (5), $f_{d}$ was evaluated as:

$f_{d}=P-Q-E T-\Delta S$

Rain gauge observations were used for $P$, eddy covariance observations were used for $E T$, and soil moisture observations were used for the variation of water in the soil layer $\left[\Delta S=\Delta \theta(1-r c) d_{s}\right.$, with soil depth $d_{s}$ equal to $0.17 \mathrm{~m}$ and rock content $r c$ equal to $10 \%$ ]. Surface runoff $Q$ was estimated using the widely known Soil Conservation Service (SCS) method 
(Chow et al., 1988; Ponce, 1989; Soil Conservation Service, 1972, 1986). We estimated the key parameter for the SCS method, the $C N$ curve number, using the results of the rainfall simulator experiments by Wilson et al. (2014), which were carried out at the same Orroli field site. To simulate the runoff coefficient of 0.8 observed in the rainfall simulator experiments of Wilson et al. (2014) (with rainfall intensity of $61.6 \mathrm{~mm} / \mathrm{h}$ and wet antecedent moisture conditions [AMC]), a $C N$ value of 89 (for AMC II; Ponce, 1989) was calibrated and used here to estimate $Q$. Runoff $Q$ was first estimated on a daily time scale, which is appropriate for the SCS method, and then aggregated to the monthly time scale to compute soil water balance. Hence, knowing $P, Q$, $E T$, and $\Delta S, f_{d}$ can be estimated from Equation (6).

\section{RESULTS}

Meteorological forcing variables are shown in Figure 1, where $P A R, V P D, \xi_{a}$, and precipitation daily time series are reported. The observation period covered part of summer (from August 31 to September 23), all of fall, and part of winter, which involved a wide range of meteorological conditions. Indeed, $P A R$ reached $10 \mathrm{mmol} \mathrm{m} \mathrm{m}^{-2} \mathrm{~d}^{-1}$ in summer and decreased to $3-4 \mathrm{mmol} \mathrm{m}^{-2} \mathrm{~d}^{-1}$ in winter (Figure 1a), and $V P D$, which was close to $3 \mathrm{KPa}$ during the summer, decreased to values lower than $0.5 \mathrm{KPa}$ during fall and winter (Figure 1b). A similar negative trend was observed for $\xi_{a}$, which decreased from $\sim 27^{\circ} \mathrm{C}$ in summer to $\sim 5^{\circ} \mathrm{C}$ in winter (Figure $1 \mathrm{c}$ ). In contrast, soil moisture started drying out in summer and, after several rain events, increased to reach saturated conditions in late fall (Figure 1d).

\section{Transpiration at tree scale}

A general decrease in tree transpiration as estimated using sap flux sensors was observed from the end of summer to winter (Figure 2a) due to energy and atmospheric constraints, as was clearly shown in the decrease of $P A R, V P D$, and $\xi_{a}$ (Figure 1). $T_{t}^{S F}$ was high in the summer (up to $2.5 \mathrm{~mm} / \mathrm{d}$ ), slightly lower in the fall (average $1.8 \mathrm{~mm} / \mathrm{d}$ ), and reached its lowest values $(<1 \mathrm{~mm} / \mathrm{d})$ at the end of the year. $T_{t}^{S F}$ was then compared with the energy balance estimate of transpiration $\left(T_{t}^{E B}\right)$ (Figure 2a). The two independent daily estimates of tree transpiration closely agreed (root mean square difference of $0.45 \mathrm{~mm} / \mathrm{d}, T_{t}^{S F}=$ $0.74 T_{t}^{E B}+0.33, \mathrm{R}^{2}=0.68, \mathrm{p}<0.001$, forcing the relationship through zero resulted in a slope of 0.89 with similar statistics), with similar means and standard deviations (mean $T_{t}^{S F}$ of 1.50 $\mathrm{mm} / \mathrm{d}[\mathrm{SD}=0.7 \mathrm{~mm} / \mathrm{d}]$ and mean $T_{t}^{E B}$ of $1.64 \mathrm{~mm} / \mathrm{d}[\mathrm{SD}=0.8$ $\mathrm{mm} / \mathrm{d}]$ ). Hence, considering the reasonable agreement between the two estimates, we can conclude that tree transpiration was accurately estimated.

Soil moisture content was very low at the beginning of the observation period, but two intense storms on DOY $=247$ and 268 of 2011 led to an increase of $\theta$ up to 0.35 (Figure 1d). Rainfall events in November 2011 (from 18 to 22 November) then brought the soil close to saturation. However, $T_{t}^{S F}$ of the wild olive tree was almost insensitive to the low soil moisture in the first half of the observation period (Figures 2). Indeed, high rates of transpiration were still observed during a long dry period (from 10 October to 4 November; Figure 1d), with a
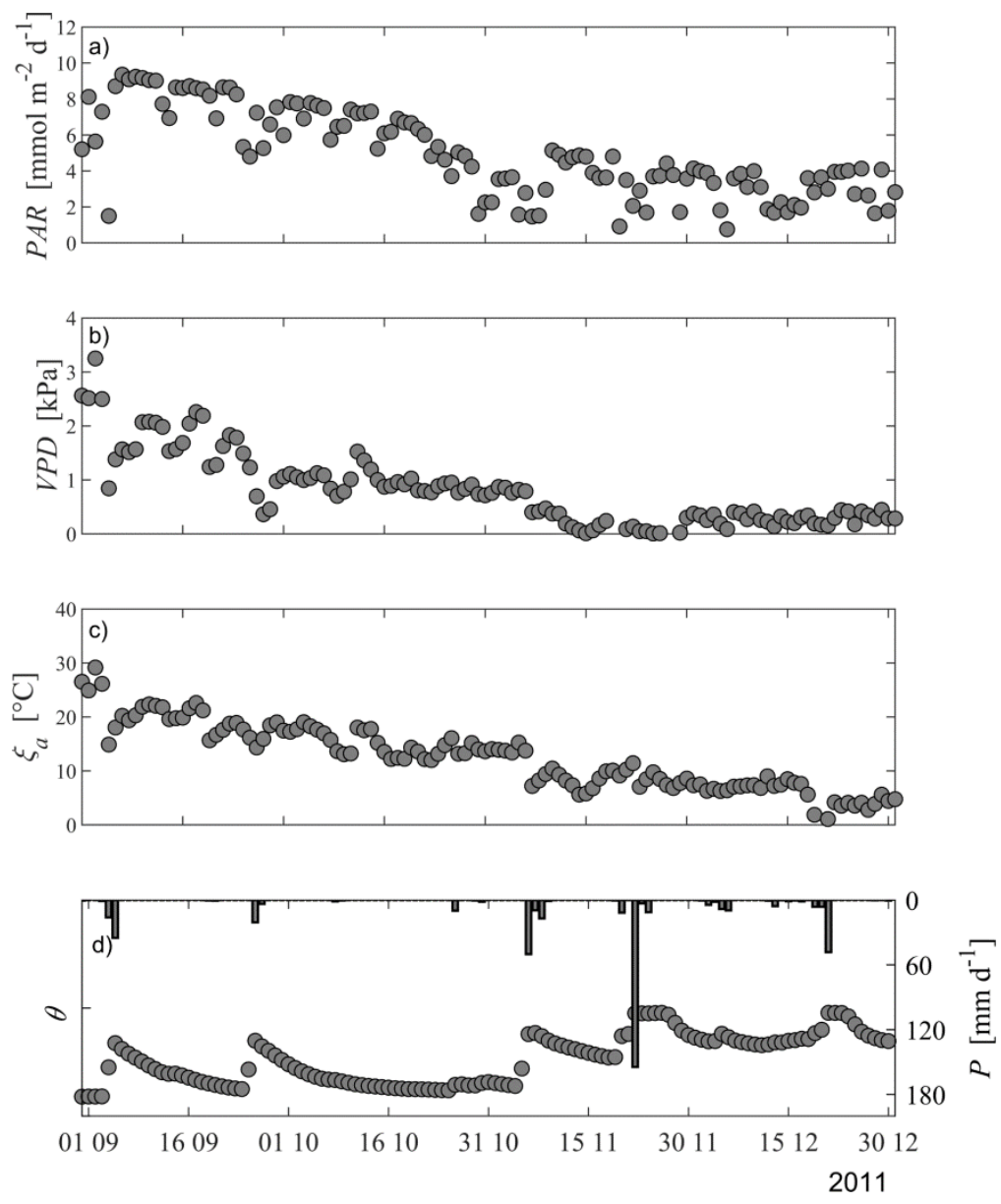

Fig. 1. Environmental conditions at the Orroli site: daily data for (a) photosynthetically active radiation (PAR); (b) vapor pressure deficit $(V P D)$; (c) air temperature $\left(\xi_{a}\right)$; (d) soil moisture $(\theta)$ and precipitation $(P)$. 

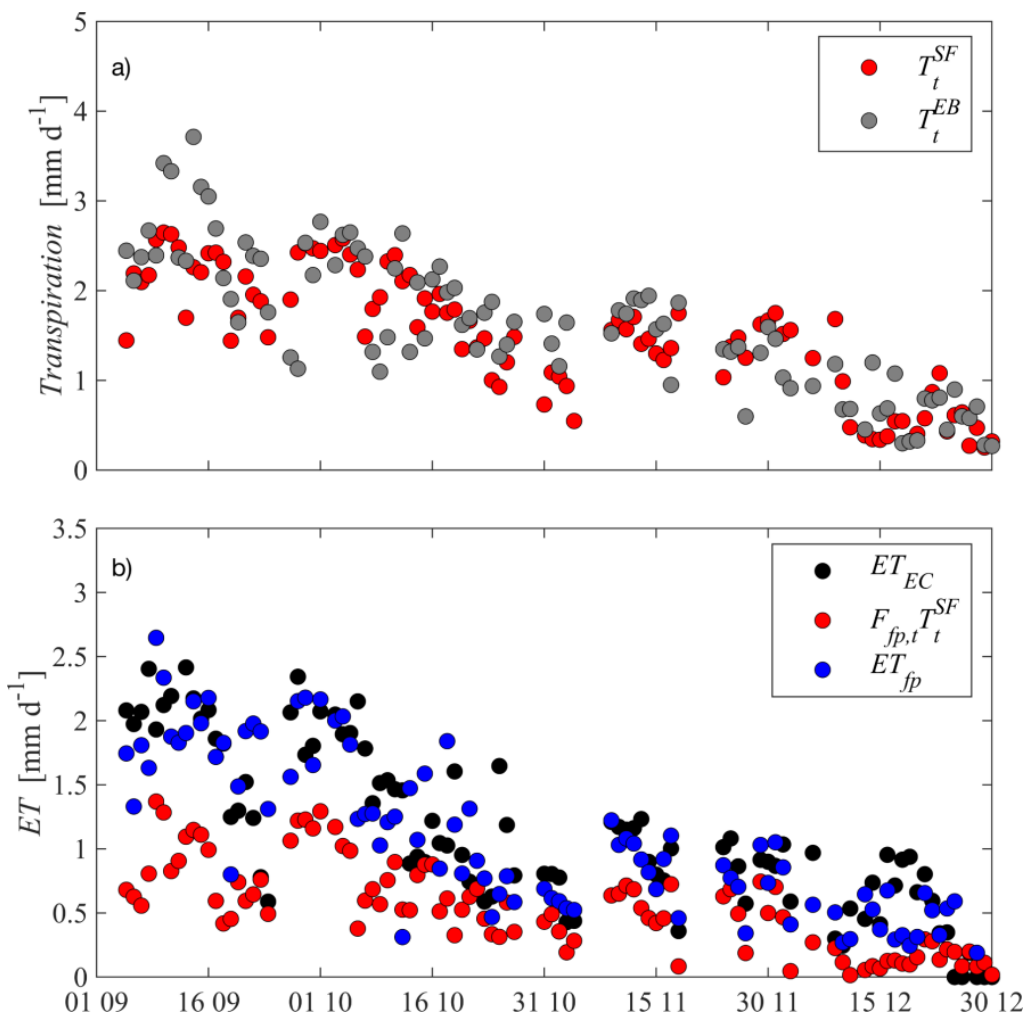

Fig. 2. (a) Daily estimates of tree transpiration using sap flow sensor measurements $\left(T_{t}^{S F}\right)$ and the energy balance approach $\left(T_{t}^{E B}\right)$; (b) Evapotranspiration $(E T)$ at the eddy covariance footprint scale: daily time series of eddy covariance-based evapotranspiration $\left(E T_{E C}\right)$, sap flux-based transpiration $\left(F_{f p, t} T_{t}^{S F}\right)$, and ecosystem $E T\left(E T_{f p}\right)$ given by Equation (4).

mean value of transpiration equal to $\sim 1.5 \mathrm{~mm} / \mathrm{d}$ and a mean value of $\theta$ equal to $\sim 0.15$. The effect of low soil moisture on tree transpiration is well depicted in Figure 3, which shows the $\beta$-function computed across a wide range of $\theta$ during a dry period (from 26 September to 25 October), with $V P D$ and $P A R$ not limiting (Figure 1 and Figure 2a). The values of $\beta$ were almost insensitive to changes in surface soil moisture, and the $\beta$-function never fell below 0.6 , with the lowest point reached when the soil moisture content also reached its lowest value (Figure 3). We compared these results with observations in cultivated rainfed olive trees in Tunisia (Ennajeh et al., 2008) and Italy (Sofo et al., 2008), where instead, as expected, $\beta$ proportionally decreased with soil moisture below a limiting soil moisture $\left(\theta_{l}\right)$ reaching almost zero values (Figure 3 ). We then further compared $\beta$ estimates with the recent observations of Montaldo et al. (2020) at the same site in a dry period during 2015 (from 18 June to 19 July). $\beta$ values were similar to those observed in 2011 (the minimum value of $\beta$ was a little lower, equal to 0.52 , although soil reached drier conditions), confirming the low sensitivity of $\beta$ to $\theta$ (Figure 3).

Although wild olives are tolerant to water stress (Lo Gullo and Salleo, 1988), they cannot transpire at rates close to potential without a water source, so that in our field, an additional water resource supported the wild olive survival. This resource may be the water in the underlying fractured basalt, taken up by the wild olive roots in the rock. We will estimate this water flux, computing $f_{d}$ using Equation (6).

\section{Evapotranspiration at the eddy-covariance footprint scale}

To compute $f_{d}$ from Equation (6), we needed to estimate $E T$. First, we estimated $E T$ using the eddy-covariance method. $E T_{E C}$ decreased from $2-2.5 \mathrm{~mm} / \mathrm{d}$ at the end of summer (due to a few rain events, Figure 1d) to less than $1 \mathrm{~mm} / \mathrm{d}$ in late fall and win- ter (Figure 2b). Sap flux measurements were scaled to the eddycovariance footprint $\left(F_{f p, t} T_{t}^{S F}\right)$, exhibiting lower values than $E T_{E C}$. Neither soil evaporation nor grass transpiration were included in $\left(F_{f p, t} T_{t}^{S F}\right)$, so large differences were observed between $F_{f p, t} T_{t}^{S F}$, and $E T_{E C}$ in general (mean $F_{f p, t} T_{t}^{S F}=0.54 \mathrm{~mm} / \mathrm{d}$ $[\mathrm{SD}=0.35 \mathrm{~mm} / \mathrm{d}]$, mean $E T_{E C}=1.13 \mathrm{~mm} / \mathrm{d}[\mathrm{SD}=0.64 \mathrm{~mm} / \mathrm{d}]$, root mean square difference of $0.2 \mathrm{~mm} / \mathrm{d}$, and $\mathrm{R}^{2}=0.6$ with $\mathrm{p}<$ 0.001 ; Figure 2b). Using Equation (4), we added $E_{b s}$ and $T_{g}$ and estimated $E T_{f p}$; the estimate of $E T_{f p}$ agreed well with the estimated $E T_{E C}\left(\right.$ mean $E T_{f p}=1.1 \mathrm{~mm} / \mathrm{d}[\mathrm{SD}=0.6 \mathrm{~mm} / \mathrm{d}]$; root mean square difference of $0.38 \mathrm{~mm} / \mathrm{d}, E T_{f p}=0.8 E T_{E C}+0.14$, $\mathrm{R}^{2}=0.64$ with $\left.\mathrm{p}<0.0001\right)$. The intercept of the relationship between $E T_{f p}$ and $E T_{E C}$ was not significantly different from zero $(\mathrm{p}=0.155)$; forcing the relationship through zero resulted in a slope of 0.90 with similar statistics, confirming the reliability of the $E T_{E C}$ estimate. Large differences between $F_{f p, t} T_{t}^{S F}$ and $E T_{E C}$ were observed during periods with higher $\theta$ (e.g., in September and from 9 November to 30 December of 2011), when soil evaporation was high, and during late fall and winter, when $T_{g}$ also increased.

We compared the differences between $F_{f p, t} T_{t}^{S F}$ and $E T_{E C}$ in the wet September 2011 with those of the dry September 2014 reported in Montaldo et al. (2020). The potential evaporation was similar (mean PE $=3.75 \mathrm{~mm} / \mathrm{d}$ in September 2011, and mean $\mathrm{PE}=3.78 \mathrm{~mm} / \mathrm{d}$ in September 2014), while the differences in precipitation $(\mathrm{P}=79 \mathrm{~mm}$ in September 2011 and $\mathrm{P}=8$ $\mathrm{mm}$ in September 2014) impacted $E T_{E C}$, which was almost five times greater in the wet September 2011 (mean $E T_{E C}=1.8$ $\mathrm{mm} / \mathrm{d}$ ) than in the dry September 2014 (mean $E T_{E C}=0.4$ $\mathrm{mm} / \mathrm{d}$ ) (Figure 4). Instead tree transpiration was almost insensitive to the monthly precipitation, with similar values (mean $F_{f p, t} T_{t}^{S F}=0.5 \mathrm{~mm} / \mathrm{d}$ in September 2011 and mean $F_{f p, t} T_{t}^{S F}=0.4$ $\mathrm{mm} / \mathrm{d}$ in September 2014) in the two contrasting 


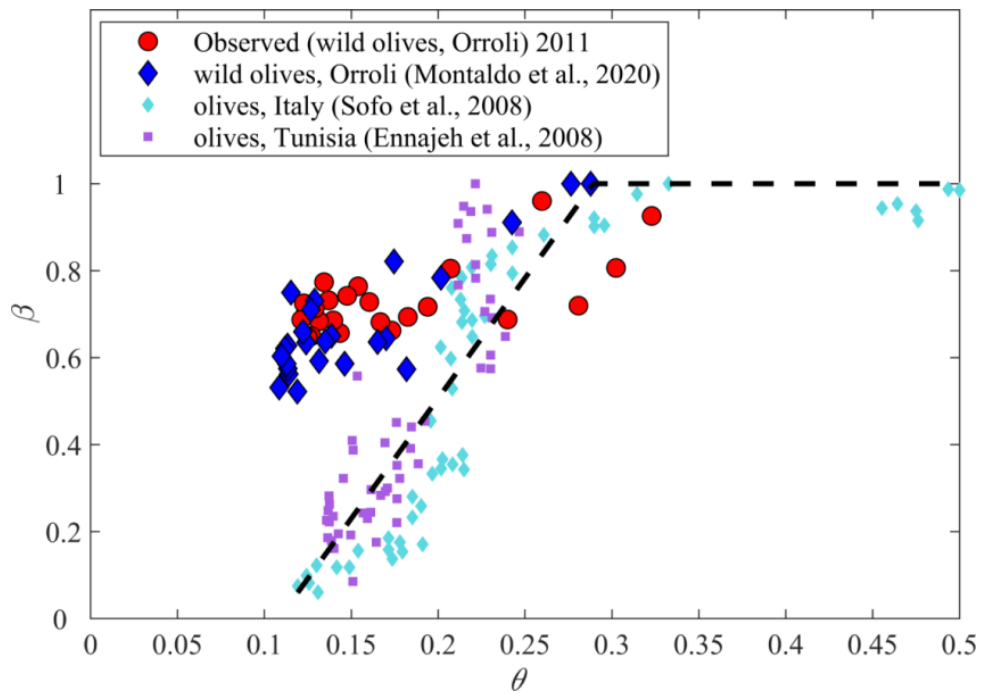

Fig. 3. $\beta$-function (ratio between tree transpiration and potential evaporation) estimates based on sap flux measurements in the wild olives of the Orroli site (red circles) versus soil moisture $(\theta)$. For comparison, $\beta$-function estimated using Montaldo et al. (2020) data at the Orroli site, and the experimental data of Sofo et al. (2008) and Ennajeh et al. (2008) in cultivated olives, with their fitted $\beta$-function (black dashed line; note that we estimated the fitted line), which increases linearly with $\theta$ below a limiting soil moisture of $\approx 0.3$, and equal to 1 for higher values.

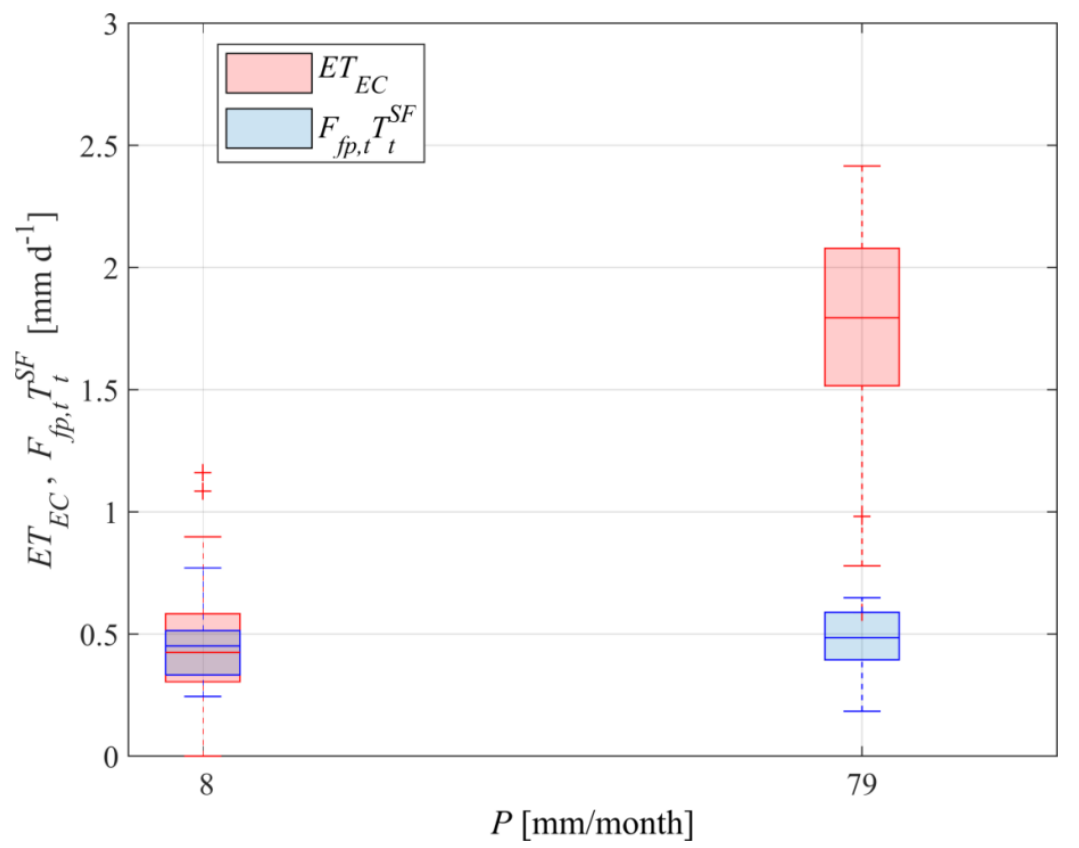

Fig. 4. The evapotranspiration $\left(E T_{E C}\right)$ and the transpiration at the footprint scale $\left(F_{f p, t} T_{t}^{S F}\right)$ of the wet September 2011 (with precipitation, $P$, of $79 \mathrm{~mm} / \mathrm{month})$ and the dry September $2014(P=8 \mathrm{~mm} / \mathrm{month})$ of Montaldo et al. (2020). The box and whiskers represent quartiles, outliers are depicted individually, and lines indicate means.

September (Figure 4). This suggested that an additional water resource supported wild olive survival in the dry September 2014, and, again, this water resource may be in the underlying fractured basalt (i.e., $f_{d}$ ).

\section{Soil water balance}

We estimated the soil water budget terms of Equation (6) on a monthly scale. We derived the vertical flux through the bottom of the soil layer from the underlying substrate $\left(f_{d}\right)$ using the eddy covariance estimate of $E T$, the observed water content variation in the soil layer $(\Delta S)$, the observed $P$ from the rain gauge, and the estimates of $Q$ (Figure 5). Across the SF-period, $f_{d}$ was downward (i.e., positive) in November and December 2011, meaning that drainage was recharging the reservoirs in the fractured rocky layer, while $f_{d}$ was negative during the previous dry months of September and October 2011. In the two dry months, the trees absorbed water (a total of $37 \mathrm{~mm}$ ) from the rocky substratum to sustain their transpiration (34\% of ET in September 2011 and $42 \%$ of ET in October 2011).

Because the SF-period started just before September, which was a dry month, and is also the start of the Sardinian hydrologic year, we extended the estimate of soil water balance to the previous hydrologic year (September 2010-August 2011). This verified that the water recharge of the fractured rock reservoir during the wet seasons of the previous 2010/11 hydrologic year was sufficient to sustain the root water uptake from the rocky substratum in September-October 2011 (Figure 6). In October 2010, rain increased soil water content (positive 

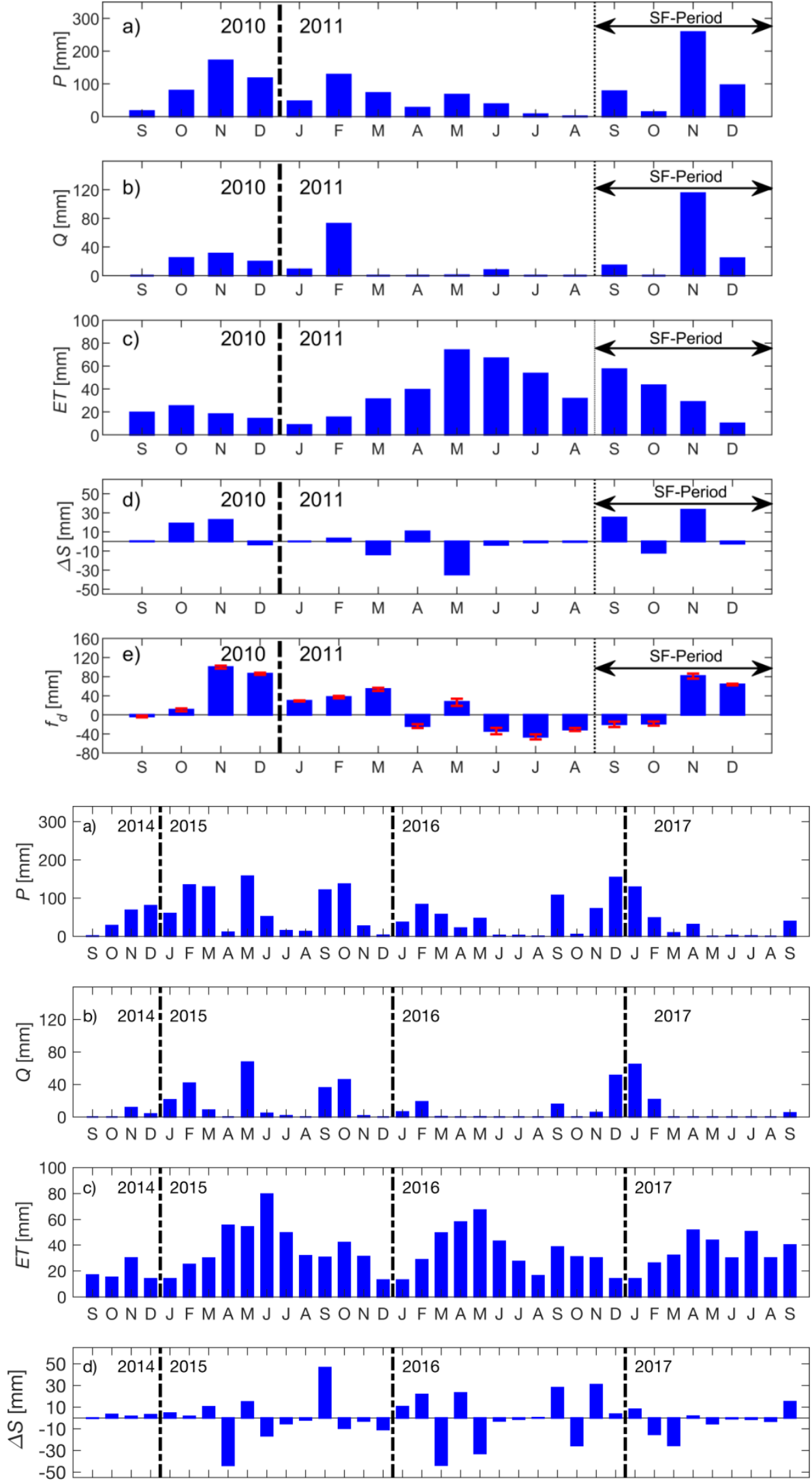

SONDJFMAMJ JASONDJFMAMJ JASONDJFMAMJ JAS

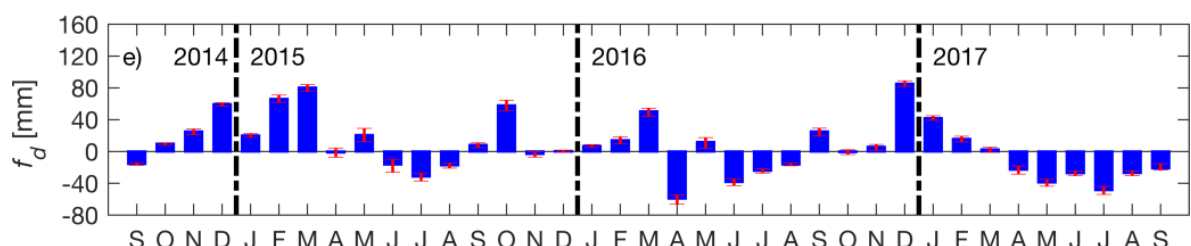

Fig. 5. Monthly soil water balance components (in $\mathrm{mm} /$ month) for the sap flux observation period ("SF-period", AugustDecember 2011) and the previous hydrologic year $(2010 / 11)$ at the Orroli site: (a) precipitation $(P)$; (b) runoff $(Q)$, (c) evapotranspiration $(E T)$; (d) variation in soil water content $(\Delta S)$; and (e) vertical flux through the bottom of the soil layer $\left(f_{d}\right)$ (the $5^{\text {th }}$ and $95^{\text {th }}$ percentiles of the 2000 runs of the $f_{d}$ sensitivity analysis are also reported).

Fig. 6. Monthly soil water balance components (in $\mathrm{mm} / \mathrm{month}$ ) for the 2014/2015, 2015/2016 and $2016 / 2017$ hydrologic years at the Orroli site: (a) precipitation $(P)$; (b) runoff $(Q)$; (c) evapotranspiration $(E T)$; (d) variation in soil water content $(\Delta S)$; and (e) vertical flux through the bottom of the soil layer $\left(f_{d}\right)$ (the $5^{\text {th }}$ and $95^{\text {th }}$ percentiles of the 2000 runs of the $f_{d}$ sensitivity analysis are also reported). 
$\Delta S$ of $19 \mathrm{~mm}$ ), so from November 2010, $P$ produced drainage (positive $f_{d}$ of $\left.90 \mathrm{~mm}\right)$. ET was low during fall 2010 ( 30 $\mathrm{mm} / \mathrm{month}$ ) before rising in spring 2011, reaching its highest value in May (=74 mm, Figure $5 \mathrm{~b})$. The variation in soil water content $(\Delta S)$ was positive in the first months of fall, negative at the end of spring, and mostly negligible in winter and summer (Figure 5c). In summer 2011, large negative values of $f_{d}$ were evaluated (a total of $-110 \mathrm{~mm}$ ), and $f_{d}$ reached a maximum value of $97 \%$ of $E T$ in August 2011. When computing the annual water budget of the $2010 / 11$ hydrologic year $(P=767.4$ $\mathrm{mm}, Q=164 \mathrm{~mm}, E T=520 \mathrm{~mm}$, and $\Delta S \sim 0 \mathrm{~mm})$, we estimated a positive total $f_{d}$ of $85 \mathrm{~mm}$ (that is, by summing all the monthly values of $f_{d}$ ), which was greater than $37 \mathrm{~mm}$ (the negative total $f_{d}$ of September-October 2011). The water uptake of the roots in the rocks during the dry months (September and October 2011) of the SF-period was thus made possible by the large recharge from the rocky reservoir during the fall and winter of the previous 2010/11 hydrologic year.

We further extended the analysis using Montaldo et al.'s (2020) database for the same site, which included the hydrologic years 2014/2015, 2015/2016 and 2016/2017 (Figure 6). Values of $f_{d}$ were generally positive in autumn and winter except in the 2015/16 hydrologic year, because the last two months of 2015 and January 2016 were unusually dry, and $f_{d}$ was negligible due to the equilibrium between rain and $E T$, both small. The highest negative value of $f_{d}$ was reached in April $2016\left(f_{d}=-60 \mathrm{~mm}\right)$. An unusually long dry period started in March 2017, producing negative $f_{d}$ in spring and summer 2017 (Figure 6), balanced by the earlier large drainage in autumn 2016 and winter 2017. Generally we note water uptake of the roots in the rocks during dry months (when the surface soil moisture was not enough for supporting evapotranspiration needs), and a recharge of the rocky reservoir during fall and winter (Figures 5 and 7).
From the ERT information we note fractures, cracks, solid rocks (characterized by electrical resistivity values higher than $350 \mathrm{Ohm} \mathrm{m})$, and low electrical resistivity $(<50 \mathrm{Ohm} \mathrm{m})$ parts, which suggest wet soils (Figure 7). The ERT images confirmed qualitatively that trees can uptake water from the roots in fractured rocks for transpiration, even if surface soil is dry.

Because positive $f_{d}$ values recharged the rocky reservoir and balanced the negative $f_{d}$ of dry months, we can expect that the sum of monthly $f_{d}$ will be positive for ecosystem sustainability on a yearly time scale. Using the entire database from 2003 (Detto et al., 2006; Montaldo et al., 2008), we computed the sum of monthly $f_{d}$ for the hydrologic years, which were characterized by strong annual precipitation variability in Sardinia (Figure 8). The sum of monthly $f_{d}$ was positive for all years, increasing with annual precipitation $\left(P_{y}\right)$ up to $200-240 \mathrm{~mm}$ for $P_{y}>750 \mathrm{~mm}$. In contrast the sum of monthly $f_{d}$ approached 0 for $P_{y}<550 \mathrm{~mm}$ (Figure 8), which resulted in a threshold for the water budget that ensured the survival of the trees in the ecosystem. Instead, as expected, annual $E T$ was not sensitive to $P_{y}$, ranging from 390-460 mm (Figure 8), in agreement with Montaldo and Oren (2018), because evapotranspiration variability in this Sardinian area is mainly controlled by the seasonal variability in precipitation (Montaldo and Oren, 2018). Finally, we also performed a sensitivity analysis of $f_{d}$ to uncertainties in the measured flux of Equation (6). Using a Monte Carlo simulation framework, we generated 2000 simulations varying the measured terms of Equation (6) simultaneously and independently through the inclusion of uncertainties in each term $[2 \%$ for $P$ (instrument accuracy), 20\% for ET (Mauder et al., 2013; Wang et al., 2015), $5 \%$ for $\Delta S$ (instrument accuracy), and $10 \%$ for $C N$, which is the key parameter for the $Q$ estimation]. The $5^{\text {th }}$ and $95^{\text {th }}$ percentiles of the ensembles of $f_{d}$ predictions are plotted in the Figures $6 \mathrm{e}$ and $7 \mathrm{e}$. The low sensitivity of $f_{d}$ predictions for all the four hydrologic years confirmed the robustness of the results.
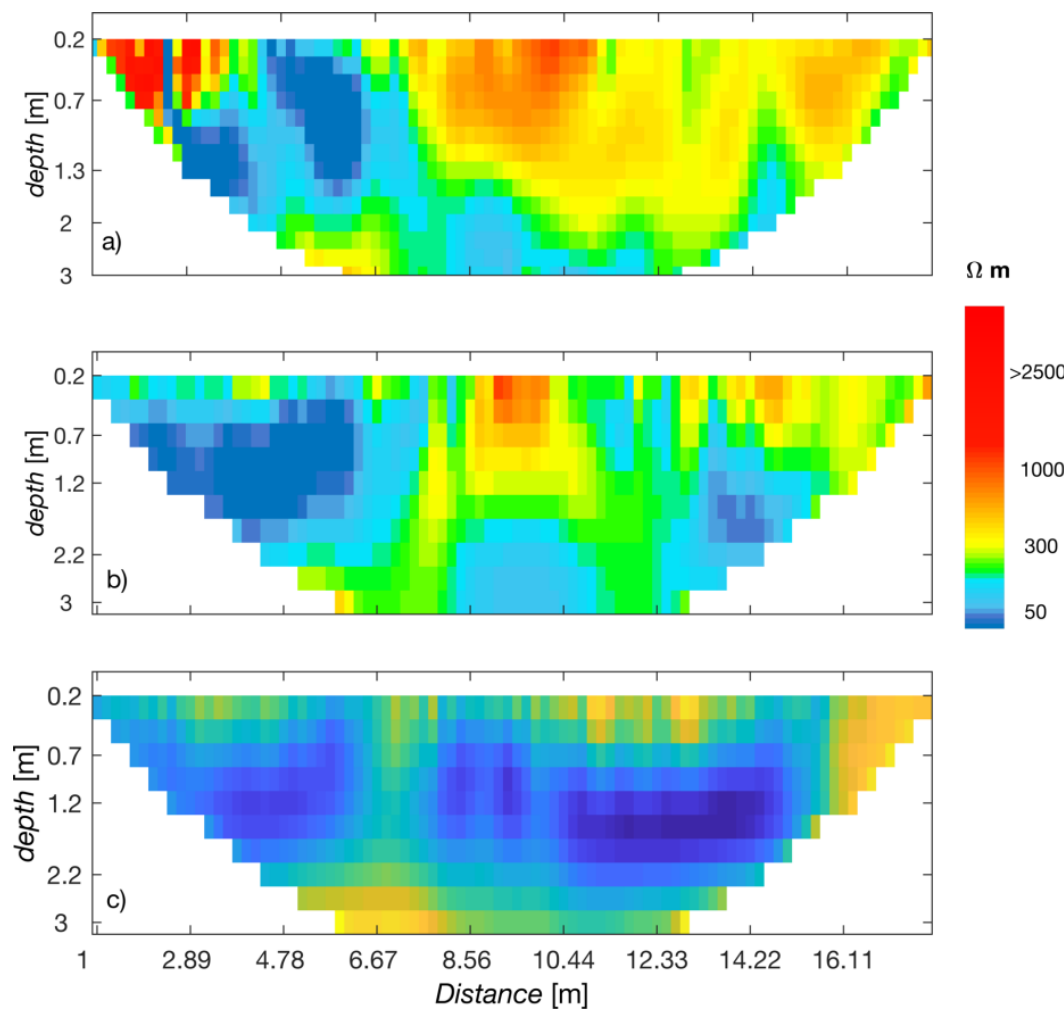

Fig. 7. Inverse model electrical resistivity (in Ohm m) tomography (ERT, unite electrode spacing of $0.50 \mathrm{~m}$ ) images of 3 transects at the distance of 2, 5 and $8 \mathrm{~m}$ from a tree clump (panels a, b, and c respectively). Fractured rock and solid rock are associated with electrical resistivity higher than 350 and $1000 \mathrm{Ohm}$ m respectively, while low values indicate the presence of wet soils. 


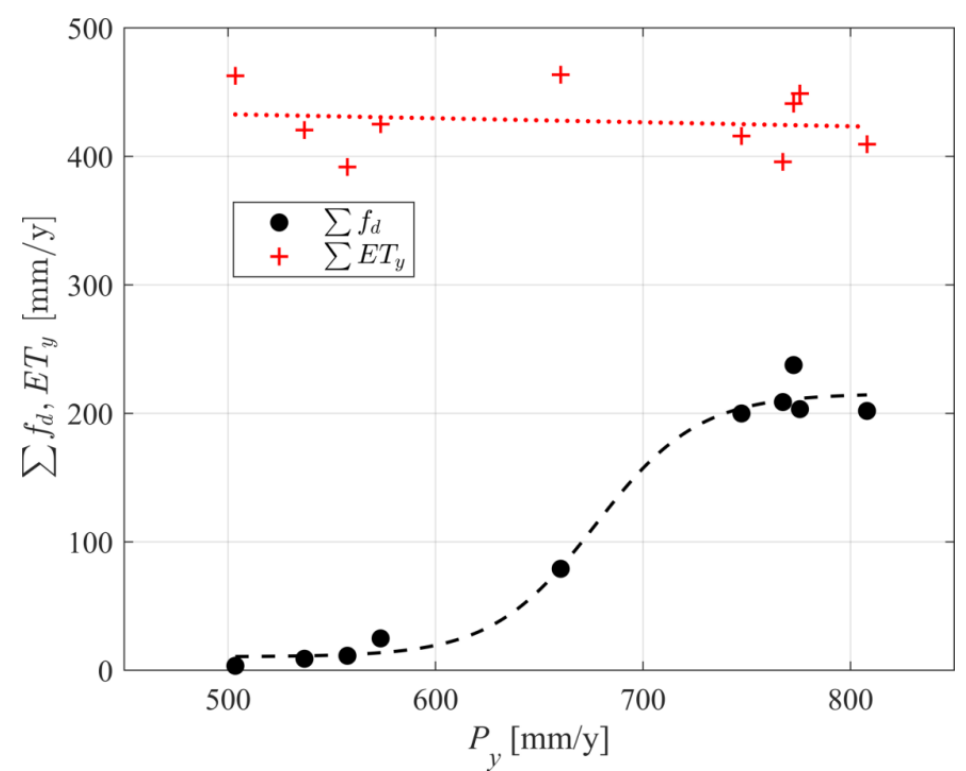

Fig. 8. The annual evapotranspiration $\left(E T_{y}\right)$ and the annual sum of $f_{d}\left(\Sigma f_{d}\right)$ versus annual precipitation $\left(P_{y}\right)$ at the Orroli site. Data from 2003 (note: incomplete years were excluded). The dotted red line is the regression line between $E T_{y}$ and $P_{y}\left(E T_{y}=447.6-0.1 P_{y} ; \mathrm{R}^{2}=0.02\right.$, $\mathrm{p}=0.7)$, and the dashed black line is the regression line between $\Sigma f_{d}$ and $P_{y}\left(\Sigma f_{d}=7.5+208.2 /\left(1+\mathrm{e}^{-(P y-676.2) / 25.5} ; \mathrm{R}^{2}=0.99, \mathrm{p}<0.0001\right)\right.$.

\section{DISCUSSION AND CONCLUSIONS}

Although wild olive trees are common in Mediterranean regions (Lumaret and Ouazzani, 2001; Terral et al., 2004), their transpiration and their sensitivity to soil moisture have rarely been investigated (Lo Gullo and Salleo, 1988; Fernández et al., 1997). Using sap flow sensor measurements, we measured a high transpiration of wild olive trees in Sardinia at the end of a dry summer in 2011 (Figure 2a). This agrees with independent estimates of tree transpiration based on energy balance (Figure 2a), and with Montaldo et al.'s (2020) recent results at the Orroli site during the dry September 2014 (Figure 4). The values of the $\beta$-function still exceeded 0.6 when soil moisture content was at its lowest (Figure 3), in agreement with the results of Detto et al. (2006), who estimated the $\beta$-functions for wild olive during another summer period at the Orroli site (summer 2003) using a different approach, and consistent with the $\beta$-function that we estimated using the recent Montaldo et al. (2020) transpiration observations (Figure 3). Instead, our results are in contrast with observations of cultivated rainfed olives in the Mediterranean region (Ennajeh et al., 2008; Sofo et al., 2008), and the common rule (Karray et al., 2008; Kutílek and Nielsen, 1994; Laio et al., 2001; Larcher, 1995; Nadezhdina et al., 2015; Rallo and Provenzano, 2013; Verhoef and Egea, 2014) of $\beta$ decreasing with soil moisture below a limiting soil moisture. Generally, it is not unusual that wild genotypes are more tolerant to environmental stresses than other genotypes of the same plant species (Liphschitz et al., 1991; Saykhul et al., 2016). Actually, wild olive can develop an adaptation strategy to rely on a range of avoidance and tolerance mechanisms which maintain internal water status and metabolic activity during dry periods (Connor et al., 2005; Fernandez et al., 1997; Lo Gullo and Salleo, 1988; Ramos and Santos, 2009). This strategy consists of the control of transpiration and water uptake of roots developed in deep soil layers (Nadezhdina et al., 2015). In the Sardinian case study, however, the wild olive grew in shallow soil that was dry for a long period, and the only way for the trees to survive was for their roots to expand into the underlying fractured basalt. In this way, trees can survive dry periods using water infiltrated into fractured rock during previous wet seasons and held in soil pockets (Cannon, 1911;
Estrada-Medina et al., 2013). We observed tree roots penetrating vertically into the fractured basalt and, using ERT, we detected fractures, cracks, water, and soil pockets in the underlying basalt (Figure 7).

We proposed to compute tree root uptake from the fractured rock using the monthly soil water balance, estimating the vertical flux from the underlying rock substrate $\left(f_{d}\right)$ as the residual term (Equation (6)), knowing ET, $P, \Delta S$ and $Q . E T$ was the key term of (6), and after demonstrating the reliability of the eddy covariance method for ET estimates, we used these estimates of $E T$ in Equation (6). We estimated high positive values for $f_{d}$ (up to $90 \mathrm{~mm} / \mathrm{month}$ in November 2010; Figure 4) during wet months. In wet periods, water infiltrated downward in the fractured rock, producing an essential "water reservoir". Indeed, tree roots used the water reservoir from the rock to sustain tree transpiration during dry periods (negative $f_{d}$ ). We estimated the highest negative $f_{d}$ in July 2011 ( $-45 \mathrm{~mm} /$ month), and we obtained an $f_{d}$ value of $-30 \mathrm{~mm} / \mathrm{month}$ in August 2011 when $f_{d}$ was $97 \%$ of ET. Considering the 2014-2017 period observed by Montaldo et al. (2020), the negative value of $f_{d}$ was even higher $(=-59 \mathrm{~mm} / \mathrm{month})$ in April 2016, when $f_{d}$ almost reached the $100 \%$ of $E T$, consistent with previous estimates (Breshears et al., 2009; Eliades et al., 2018; McCole and Stern, 2007; Schwinning, 2010).

The wild olive tolerated dry conditions in the Sardinia case study and still transpired at high rates thanks to water uptake by roots in fractured rock. As do other tree species in Mediterranean regions, wild olive trees continue physiological activity and maintain transpiration even during drought, when the moisture of the thin soil layer is at a minimum. Trees in arid and semiarid regions often grow on thin soils overlaying fractured bedrock or cemented horizons (Allen, 2009; Barbeta et al., 2015; Bornyasz et al., 2005; Breshears et al., 2009; Lewis and Burgy, 1964), with roots penetrating the rocky substratum through cracks, fractures, and dissolution features (Cannon, 1911). The water uptake of roots in rock has been observed in coast live oak in California (Bornyasz et al., 2005), oak in Pennsylvania (Hasenmueller et al., 2017); chaparral shrub in south California (Graham et al., 1997; Graham et al., 2010; Sternberg et al., 1996); holm oak in Spain (Barbeta et al., 2015); pine in New Mexico (Breshears et al., 2009), California (Hubbert et al., 
2001; Rose et al., 2003; Witty et al., 2003), Cyprus (Eliades et al., 2018), and Oregon (with Arctostaphylos viscida, Zwieniecki and Newton, 1995); juniper in Texas (Kukowski et al., 2013; McCole and Stern, 2007; Schwinning, 2008); and Gymnopodium floribundum in Mexico (Estrada-Medina et al., 2013). The potentially large source of water represented by rock fractures is usually neglected by ecohydrologists (Rempe and Dietrich, 2018), and our findings support Schwinning's (2010) challenge to elucidate the "ecohydrology of roots in rocks". We developed a method for its computation and demonstrated that the contribution of water uptake from roots in fractured rock during drought can be vital in sustaining tree transpiration under dry conditions. Such uptake must thus be considered in the ecohydrological modeling of semi-arid and arid basins.

The Sardinian site is characterized by a strong interannual variability of annual precipitation, as typical of the Mediterranean region (Giorgi et al., 2004; Montaldo et al., 2008; Ramos, 2001), and using all the data collected at the Sardinian site from 2003 , we estimated a lower limit for annual precipitation $(\sim 500$ $\mathrm{mm} / \mathrm{y}$; Figure 8) below which the recharge of rock reservoir during wet months could no longer sustain the tree's water needs during the dry months, jeopardizing the tree's survival in the ecosystem. At present, the developed woody cover percentage $(-33 \%)$ of the Sardinian site is sustainable with the historical mean annual precipitation (MAP) $(\sim 650 \mathrm{~mm} / \mathrm{y})$, according to Yang et al. (2016) and Axelsson and Hanan (2017), who estimated sustainable woody cover percentages for a large range of MAP in Africa and Texas dry ecosystems. We demonstrated that drier conditions, such as those predicted by future climate change projections in the Mediterranean area (Cayan et al., 2008; Mariotti et al., 2008; Mastrandrea and Luers, 2012; May, 2008; Ozturk et al., 2015), with a reduction of MAP up to $\sim 15 \%$ in Sardinia (Montaldo and Oren, 2018), could impact the existing tree-grass ecosystem equilibrium, decreasing the woody cover spatial distribution.

Acknowledgements. This research was funded by MIUR through the SWATCH European project of PRIMA MED program, the ALTOS European project of PRIMA MED program, and the FLUXMED European project of WATER JPI program. We acknowledge Giulio Vignoli, Gian Piero Deidda, Luca Piroddi, Luigi Michele Noli, and Mario Sitzia, for ERT measurements. We thank two anonymous reviewers for their useful comments and suggestions.

\section{REFERENCES}

Allen, M.F., 2009. Bidirectional water flows through the soilfungal-plant mycorrhizal continuum. New Phytologist, 182, 290-293. DOI: 10.1111/j.1469-8137.2009.02815.x

Altın, T.B., Barak, B., 2014. Changes and trends in total yearly precipitation of the Antalya district, Turkey. Procedia - Social and Behavioral Sciences, 120, 586-599.

Axelsson, C.R., Hanan, N.P., 2017. Patterns in woody vegetation structure across African savannas. Biogeosciences, 14, 3239-3252. https://doi.org/10.5194/bg-14-3239-2017

Baldocchi, D.D., 2003. Assessing the eddy covariance technique for evaluating carbon dioxide exchange rates of ecosystems: past, present and future. Global Change Biology, 9, 479-492. DOI: 10.1046/j.13652486.2003.00629.x

Baldocchi, D.D., Xu, L.K., Kiang, N., 2004. How plant functional-type, weather, seasonal drought, and soil physical properties alter water and energy fluxes of an oak-grass savanna and an annual grassland. Agricultural and Forest Meteorology, 123, 13-39. 10.1016/j.agrformet.2003.11.006

Balugani, E., Lubczynski, W., Reyes-Acosta, L., van der Tol, C., Francés, A.P., Metselaar, K., 2017. Groundwater and unsaturated zone evaporation and transpiration in a semi-arid open woodland. Journal of Hydrology, 547, 54-66. DOI: 10.1016/j.jhydrol.2017.01.042

Barbeta, A., Mejía-Chang, M., Ogaya, R., Voltas, J., Dawson, T.E., Peñuelas, J., 2015. The combined effects of a longterm experimental drought and an extreme drought on the use of plant-water sources in a Mediterranean forest. Global Change Biology, 21, 1213-1225. DOI: 10.1111/gcb.12785

Berkelhammer, M., Noone, D.C., Wong, T.E., Burns, S.P., Knowles, J.F., Kaushik, A., Blanken, P.D., Williams, M.W., 2016. Convergent approaches to determine an ecosystem's transpiration fraction. Global Biogeochemical Cycles, 30, 933-951. DOI: 10.1002/2016gb005392

Bornyasz, M.A., Graham, R.C., Allen, M.F., 2005. Ectomycorrhizae in a soil-weathered granitic bedrock regolith: Linking matrix resources to plants. Geoderma, 126, 141-160. DOI: 10.1016/j.geoderma.2004.11.023

Bovard, B.D., Curtis, P.S., Vogel, C.S., Su, H.B., Schmid, H.P., 2005. Environmental controls on sap flow in a northern hardwood forest. Tree Physiology, 25, 31-38.

Breshears, D.D., 2006. The grassland-forest continuum: trends in ecosystem properties for woody plant mosaics? Frontiers in Ecology and the Environment, 4, 96-104. DOI: 10.1890/1540-9295004[0096:TGCTIE]2.0.CO;2

Breshears, D.D., Myers, O.B., Barnes, F.J., 2009. Horizontal heterogeneity in the frequency of plant-available water with woodland intercanopy-canopy vegetation patch type rivals that occuring vertically by soil depth. Ecohydrology, 2, 503519. DOI: $10.1002 /$ eco.75

Brutsaert, W., 1982. Evaporation into the Atmosphere: Theory, History, and Applications. Kluwer Academic Publishers, 299 p.

Cammalleri, C., Rallo, G., Agnese, C., Ciraolo, G., Minacapilli, M., Provenzano, G., 2013. Combined use of eddy covariance and sap flow techniques for partition of ET fluxes and water stress assessment in an irrigated olive orchard. Agricultural Water Management, 120, 89-97. DOI: 10.1016/j.agwat.2012.10.003

Cannon, W.A., 1911. The Root Habits of Desert Plants. Published by the Carnegie Institution of Washington.

Cayan, D.R., Maurer, E., Dettinger, M.D., Hayhoe, K., 2008. Climate change scenarios for the California region. Climatic Change, 87, 21-42. https://doi.org/10.1007/s10584-0079377-6

Chebbi, W., Boulet, G., Le Dantec, V., Lili Chabaane, Z., Fanise, P., Mougenot, B., Ayari, H., 2018. Analysis of evapotranspiration components of a rainfed olive orchard during three contrasting years in a semi-arid climate. Agricultural and Forest Meteorology, 256, 159-178.

Chow, V., Maidment, D., Mays, L., 1988. Applied Hydrology. 2nd Ed. McGraw-Hill, New York, USA.

Connor, D.J., 2005. Adaptation of olive (Olea europaea L.) to water-limited environments. Australian Journal of Agricultural Research, 56, 1181-1189. DOI: 10.1071/ar05169

Corona, R., Montaldo, N., Albertson, J.D., 2018. On the role of NAO-driven interannual variability in rainfall seasonality on water resources and hydrologic design in a typical Mediterranean basin. Journal of Hydrometeorology, 19, 485-498. DOI: $10.1175 / \mathrm{jhm}-\mathrm{d}-17-0078.1$ 
David, T.S., Henriques, M.O., Kurz-Besson, C., et al, 2007. Water-use strategies in two co-occurring Mediterranean evergreen oaks: surviving the summer drought. Tree Physiology, 27, 793-803. DOI: 10.1093/treephys/27.6.793

Detto, M., Katul, G., Mancini, M., Montaldo, N., Albertson, J.D., 2008. Surface heterogeneity and its signature in higherorder scalar similarity relationships. Agricultural and Forest Meteorology, 148, 902-916. DOI: 10.1016/j.agrformet.2007.12.008

Detto, M., Montaldo, N., Albertson, J.D., Mancini, M., Katul, G., 2006. Soil moisture and vegetation controls on evapotranspiration in a heterogeneous Mediterranean ecosystem on Sardinia, Italy. Water Resources Research, 42, 16. DOI: $10.1029 / 2005$ wr004693

Eliades, M., Bruggeman, A., Lubczynski, M.W., Christou, A., Camera, C., Djuma, H., 2018. The water balance components of Mediterranean pine trees on a steep mountain slope during two hydrologically contrasting years. Journal of Hydrology, 562, 712-724. DOI: 10.1016/j.jhydrol.2018.05.048

Ennajeh, M., Tounekti, T., Vadel, A.M., Khemira, H., Cochard, H., 2008. Water relations and drought-induced embolism in olive (Olea europaea) varieties 'Meski' and 'Chemlali' during severe drought. Tree Physiology, 28, 6, 971-976. DOI: 10.1093/treephys/28.6.971

Estrada-Medina, H., Graham, R.C., Allen, M.F., JimenezOsornio, J.J., Robles-Casolco, S., 2013. The importance of limestone bedrock and dissolution karst features on tree root distribution in northern Yucatan, Mexico. Plant and Soil, 362, 37-50. DOI: 10.1007/s11104-012-1175-x

Fernandez, J.E., Moreno, F., Giron, I.F., Blozquez, O.M., 1997. Stomatal control of water use in olive tree leaves. Plant and Soil, 190, 179-192. DOI: 10.1023/a:1004293026973

Finnigan, J., 2004. The footprint concept in complex terrain. Agricultural and Forest Meteorology, 127, 117-129. DOI: 10.1016/j.agrformet.2004.07.008

Foken, T., 2008. The energy balance closure problem: An overview. Ecological Applications, 18, 1351-1367. DOI: 10.1890/06-0922.1

Fritschen, L.J., Simpson, J.R., 1989. Surface energy and radiation balance system: General description and improvements. Journal of Applied Meteorology, 28, 680 689.

Garratt, J.R., 1992. The Atmospheric Boundary Layer. Cambridge Univ. Press, New York.

Giorgi, F., Bi, X., Pal, J.S., 2004. Mean interannual variability and trends in a regional climate change experiment over Europe. I. Present-day climate (1961-1990). Climate Dynamics, 22, 733-756.

Graham, R.C., Rossi, A.M., Hubbert, K.R., 2010. Rock to regolith conversion: Producing hospitable substrates for terrestrial ecosystems. GSA Today, 20, 2, 4-9.

Graham, R.C., Anderson, M.A., Stemberg, P.D., Tice, K.R., Schoeneberger, P.J., et al., 1997. Morphology, porosity, and hydraulic conductivity of weathered granitic bedrock and overlying soils. Soil Science Society of America Journal, 61, 516-522. DOI: 10.2136/sssaj1997.03615995006100020021x

Granier, A., 1985. Une nouvelle méthode pour la mesure du flux de sève brute dans le tronc des 440 arbres. Ann. Sci. Forest. 42, 193-200.

Granier, A., 1987. Evaluation of transpiration in a Douglas-fir stand by means of sap flow measurements. Tree Physiology, 3, 309-320.

Hasenmueller, E.A., Gu, X., Weitzman, J.N., et al., 2017. Weathering of rock to regolith: The activity of deep roots in bedrock fractures. Geoderma, 300, 11-31. DOI: 10.1016/j.geoderma.2017.03.020

Hassler, S.K., Weiler, M., Blume, T., 2018. Tree-, stand- and site-specific controls on landscape-scale patterns of transpiration. Hydrology and Earth System Sciences, 22, 1330. DOI: $10.5194 /$ hess-22-13-2018

Holdo, R.M., Brocato, E.R., 2015. Tree-grass competition varies across select savanna tree species: a potential role for rooting depth. Plant Ecology, 216, 577-588. DOI: 10.1007/s11258-015-0460-1

Hubbert, K.R., Graham, R.C., Anderson, M.A., 2001. Soil and weathered bedrock: Components of a Jeffrey pine plantation substrate. Soil Science Society of America Journal, 65, 1255-1262. DOI: 10.2136/sssaj2001.6541255x

Jung, M., Reichstein, M., Ciais, P., et al., 2010. Recent decline in the global land evapotranspiration trend due to limited moisture supply. Nature, 467, 951-954. DOI: 10.1038/nature09396

Karray, J.A., Lhomme, J.P., Masmoudi, M.M., Mechlia N.B., 2008. Water balance of the olive tree-annual crop association: A modeling approach. Agricultural Water Management, $95, \quad 5, \quad 575-586 . \quad$ DOI: 10.1016/j.agwat.2007.12.006

Köstner, B., Granier, A., Cermak, J., 1998. Sapflow measurements in forest stands: methods and uncertainties. Annales Des Sciences Forestieres, 55, 13-27. DOI: 10.1051/forest: 19980102

Kukowski, K.R., Schwinning, S., Schwartz, B.F., 2013. Hydraulic responses to extreme drought conditions in three co-dominant tree species in shallow soil over bedrock. Oecologia, 171, 819-830. DOI: 10.1007/s00442-012-2466-x

Kurc, S.A., Small, E.E., 2004. Dynamics of evapotranspiration in semiarid grassland and shrubland ecosystems during the summer monsoon season, central New Mexico. Water Resources Research, 40. DOI: 10.1029/2004wr003068

Kutílek, M., Nielsen, D.R., 1994. Soil Hydrology. Catena Verlag.

Laio, F., Porporato, A., Ridolfi, L., Rodriguez-Iturbe, I., 2001. Plants in water-controlled ecosystems: active role in hydrologic processes and response to water stress - II. Probabilistic soil moisture dynamics. Advances in Water Resources, 24, 7, 707-723. DOI: 10.1016/s03091708(01)00005-7

Larcher, W., 1995. Physiological plant ecology. 3rd Ed. Springer, $506 \mathrm{p}$.

Lewis, D.C., Burgy, R.H., 1964. The relationship between oak tree roots and ground water in fractured rock as determined by tritium tracing. Journal of Geophysical Research, 69, 2579-2588.

Limousin, J.M., Rambal, S., Ourcival, J.M., Rocheteau A., Joffre, R., Rodriguez-Cortinta, R., 2009. Long-term transpiration change with rainfall decline in a Mediterranean Quercus ilex forest. Global Change Biology, 15, 2163-2175. DOI: $10.1111 / \mathrm{j} .1365-2486.2009 .01852 . x$

Liphschitz, N., Gophna, R., Hartman, M., Biger, G., 1991. The beginning of olive (olea europaea) cultivation in the oldworld - a reassessment. Journal of Archaeological Science, 18, 4, 441-453. DOI: 10.1016/0305-4403(91)90037-p

Liu, X.D., Li, Y, Chen, X, Zhou, G., Cheng, J., Zhang, D., Meng, Z., Zhang, Q., 2015. Partitioning evapotranspiration in an intact forested watershed in southern China. Ecohydrology, 8, 1037-1047. DOI: 10.1002/eco.1561

Lo Gullo, M.A., Salleo, S., 1988. Different strategies of drought resistance in three Mediterranean sclerophyllous trees growing in the same environmental conditions. New Phytologist, 108, 267-276. 
Lumaret, R., Ouazzani, N., 2001. Brief communications. Nature, 413.

Mariotti, A., Zeng, N., Yoon, J.H., Artale, V., Navarra, A., Alpert, P., Li, L.Z.X., 2008. Mediterranean water cycle changes: Transition to drier 21 st century conditions in observations and CMIP3 simulations. Environmental Research Letters, 3, 4, 1-8. https://doi.org/10.1088/17489326/3/4/044001

Martínez-Fernández, J., Sánchez, N., Herrero-Jiménez, C.M., 2013. Recent trends in rivers with near-natural flow regime: The case of the river headwaters in Spain. Progress Physical. Geography, 37 , 685-700. https://doi.org/10.1177/0309133313496834

Maselli, F., Chiesi, M., Bindi, M., 2004. Multi-year simulation of Mediterranean forest transpiration by the integration of NOAA-AVHRR and ancillary data. International Journal of Remote Sensing, 25, 3929-3941. DOI: $10.1080 / 01431160310001653546$

May, W., 2008. Potential future changes in the characteristics of daily precipitation in Europe simulated by the HIRHAM regional climate model. Climate Dynamics, 30, 581-603. https://doi.org/10.1007/s00382-007-0309-y

Mastrandrea, M.D., Luers, A.L., 2012. Climate change in California: Scenarios and approaches for adaptation. Climatic Change, 111, 5-16. https://doi.org/10.1007/s10584011-0240-4

Mauder, M., Cuntz, M., Drüe, C., Graf, A., Rebmann, C., Schmid, H.P., Schmidt, M., Steinbrecher, R., 2013. A strategy for quality and uncertainty assessment of long-term eddy-covariance measurements. Agricultural and Forest Meteorology, 169, 122-135.

McCole, A.A., Stern, L.A., 2007. Seasonal water use patterns of Juniperus ashei on the Edwards Plateau, Texas, based on stable isotopes in water. Journal of Hydrology, 342, 238248. DOI: 10.1016/j.jhydrol.2007.05.024

Miller, G.R., Chen, X., Rubin, Y., Ma, S., Baldocchi, D.D., 2010. Groundwater uptake by woody vegetation in a semiarid oak savanna. Water Resources Research, 46, 10. DOI: $10.1029 / 2009$ wr008902

Montaldo, N., Albertson, J.D., Mancini, M., 2008. Vegetation dynamics and soil water balance in a water-limited Mediterranean ecosystem on Sardinia, Italy. Hydrology and Earth System Sciences, 12, 1257-1271. DOI: 10.5194/hess12-1257-2008

Montaldo, N., Corona, R., Albertson, J.D., 2013. On the separate effects of soil and land cover on Mediterranean ecohydrology: Two contrasting case studies in Sardinia, Italy. Water Resources Research, 49, 1123-1136. DOI: $10.1029 / 2012 \mathrm{wr} 012171$

Montaldo, N., Oren, R., 2016. The way the wind blows matters to ecosystem water use efficiency. Agricultural and Forest Meteorology, 217, 1-9.

Montaldo, N., Sarigu, A., 2017. Potential links between the North Atlantic Oscillation and decreasing precipitation and runoff on a Mediterranean area. Journal of Hydrology, 553, 419-437. DOI: 10.1016/j.jhydrol.2017.08.018

Montaldo, N., Oren, R., 2018. Changing seasonal rainfall distribution with climate directs contrasting impacts at evapotranspiration and water yield in the Western Mediterranean Region. Earth's Future, 6. https://doi.org/10.1029/2018EF000843

Montaldo, N., Curreli, M., Corona, R., Oren, R., 2020. Fixed and variable components of evapotranspiration in a Mediterranean wild-olive - grass landscape mosaic. Agricultural and Forest Meteorology, 280, doi.org/10.1016/j.agrformet.2019.107769.

Muchingami, I., Hlatywayo, D.J., Nel, J.M., Chuma, C., 2012. Electrical resistivity survey for groundwater investigations and shallow subsurface evaluation of the basaltic-greenstone formation of the urban Bulawayo aquifer. Physics and Chemistry of the Earth, 50-52, 44-51.

Nadezhdina, N., Ferreira, M.I., Conceicao, N., Pacheco, C.A., Hausler, M., David, T.S., 2015. Water uptake and hydraulic redistribution under a seasonal climate: long-term study in a rainfed olive orchard. Ecohydrology, 8, 387-397. DOI: 10.1002/eco. 1545

Nijland, W., van der Meijde, M., Addink, E.A., de Jong, S.M., 2010. Detection of soil moisture and vegetation water abstraction in a Mediterranean natural area using electrical resistivity tomography. Catena, 81, 3, 209-216.

Oishi, A.C., Oren, R., Stoy, P.C., 2008. Estimating components of forest evapotranspiration: A footprint approach for scaling sap flux measurements. Agricultural and Forest Meteorology, 148, 1719-1732. DOI: 10.1016/j.agrformet.2008.06.013

Orellana, F., Verma, P., Loheide II, S.P.E., 2012. Monitoring and modeling water-vegetation interactions in groundwaterdependent ecosystems. Reviews of Geophysics, 50. DOI: 10.1029/2011rg000383

Oren, R., Phillips, N., Katul, G., Ewers, B.E., Pataki, D.E., 1998. Scaling xylem sap flux and soil water balance and calculating variance: a method for partitioning water flux in forests. Annales Des Sciences Forestieres, 55, 191-216. DOI: 10.1051 /forest: 19980112

Ozturk, T., Ceber, Z.P., Türkeş, M., Kurnaz, M.L., 2015. Projections of climate change in the Mediterranean Basin by using downscaled global climate model outputs. International Journal of Climatology, 35, 14, 4276-4292.

Paço, T.A., David, T.S., Henriques, M.O., Pereira, J.S., Valente, F., Banza, J., Pereira, F.L., Pinto, C., David, J.S., 2009. Evapotranspiration from a Mediterranean evergreen oak savannah: The role of trees and pasture. Journal of Hydrology, 369, 98-106. DOI: 10.1016/j.jhydrol.2009.02.011

Perez-Priego, O., El-Madany, T.S., Migliavacca, M., Kowalski, A.S., Jung, M., Carrara, A., Kolle, O., Martín, M.P., Pacheco-Labrador, J., Moreno, G., Reichstein, M., 2017. Evaluation of eddy covariance latent heat fluxes with independent lysimeter and sapflow estimates in a Mediterranean savannah ecosystem. Agricultural and Forest Meteorology, 236, 87-99. DOI: 10.1016/j.agrformet.2017.01.009

Ponce, V.M., 1989. Engeneering Hydrology: Principles and Practices. Prentice-Hall, Englewood Cliffs, New Jersey, USA.

Rallo, G., Provenzano, G., 2013. Modelling eco-physiological response of table olive trees (Olea europaea L.) to soil water deficit conditions. Agricultural Water Management, 120, 79-88. DOI: 10.1016/j.agwat.2012.10.005

Ramos, A.F., Santos, F.L., 2009. Water use, transpiration, and crop coefficients for olives (cv. Cordovil), grown in orchards in Southern Portugal. Biosystems Engineering, 102, 321333. DOI: 10.1016/j.biosystemseng.2008.12.006

Ramos, M.C., 2001. Rainfall distribution patterns and their change over time in a Mediterranean area. Theoretical and Applied Climatology, 69, 3-4, 163-170.

Rana, G., Katerji, N., 2000. Measurement and estimation of actual evapotranspiration in the field under Mediterranean climate: a review. European Journal of Agronomy, 13, 125-153.

Rempe, D.M., Dietrich, W.E., 2018. Direct observations of rock moisture, a hidden component of the hydrologic cycle. Proceedings of the National Academy of Sciences of the 
United States of America, 115, 2664-2669. DOI: $10.1073 /$ pnas. 1800141115

Reynolds, J., Kemp, P., Tenhunen, J., 2000. Effects of longterm rainfall variability on evapotranspiration and soil water distribution in the Chihuan Desert: A modeling analysis. Plant Ecology, 150, 145-159.

Rodriguez-Iturbe, I., 2000. Ecohydrology: A hydrologic perspective of climate-soil-vegetation dynamics. Water Resources Research, 36, 3-9.

Rodriguez-Robles, U., Arredondo, T., Huber-Sannwald, E., Ramos-Leal, A., Yépez, E.A., 2017. Technical note: Application of geophysical tools for tree root studies in forest ecosystems in complex soils. Biogeosciences, 14, 5343-5357. DOI: 10.5194/bg-14-5343-2017

Rose, K.L., Graham, R.C., Parker, D.R., 2003. Water source utilization by Pinus jeffreyi and Arctostaphylos patula on thin soils over bedrock. Oecologia, 134, 46-54. DOI: 10.1007/s00442-002-1084-4

Sankaran, M., et al., 2005. Determinants of woody cover in African savannas. Nature, 438, 846-849. DOI: 10.1038/nature 04070

Saykhul, A., Chatzistathis, T., Chatzissavvidis, C., Therios, I., Menexes, G., 2016. Root growth of cultivated and "wild" olive in response to potassium mineral nutrition. Journal of Plant Nutrition, 39, 11, 1513-1523. DOI: 10.1080/01904167.2016.1143503

Scholes, R.J., Archer, S.R., 1997. Tree-grass interactions in savannas. Annual Review of Ecology and Systematics., 28, 517-544.

Schwinning, S., 2008. The water relations of two evergreen tree species in a karst savanna. Oecologia, 158, 373-383. DOI: $10.1007 / \mathrm{s} 00442-008-1147-2$

Schwinning, S., 2010. The ecohydrology of roots in rocks. Ecohydrology, 3, 238-245. DOI: 10.1002/eco.134

Sofo, A., Manfreda, S., Fiorentino, M., Dichio, B., Xiloyannis, C., 2008. The olive tree: a paradigm for drought tolerance in Mediterranean climates. Hydrology and Earth System Sciences, 12, 1, 293-301. DOI: 10.5194/hess-12-293-2008

Soil Conservation Service, 1972. National Engineering Handbook, Hydrology. Section 4. US Department of Agriculture: Washington, DC.

Soil Conservation Service, 1986. National Engineering Handbook. Section 4: Hydrology, Soil Conservation Service, USDA, Washington, D.C.

Steppe, K., Vandegehuchte, M.W., Tognetti, R., Mencuccini, M., 2015. Sap flow as a key trait in the understanding of plant hydraulic functioning. Tree Physiology, 35, 341-345. DOI: $10.1093 /$ treephys/tpv033

Sternberg, P.D., Anderson, M.A., Graham, R.C., Beyers, J.L., Tice, K.R., 1996. Root distribution and seasonal water status in weathered granitic bedrock under chaparral. Geoderma, 72, 89-98. DOI: 10.1016/0016-7061(96)00019-5

Stull, R.B., 1988. An Introduction to Boundary Layer Meteorology. Kluwer Academic Publishers.

Terral, J.F., Badal, E., Heinz, C., Roiron, P., Thiebault, S., Figueiral, I., 2004. A hydraulic conductivity model points to post-Neogene survival of the Mediterranean olive. Ecology, 85, 3158-3165. DOI: 10.1890/03-3081

Tognetti, R., Costagli, G., Minnocci, A., Gucci, R., 2004. Irrigation effects on daily and seasonal variations of trunk sap flow and leaf water relations in olive trees. Plant and Soil, 263, 1-2, 249-264. DOI: 10.1023/b:plso.0000047738.96931.91

Travelletti, J., Malet, J.-P., 2012. Hydrological response of weathered clay-shale slopes: water infiltration monitoring with time-lapse electrical resistivity tomography.
Hydrological Processes, 26, 2106-2119. DOI: 10.1002/hyp.7983

UP Sap Flow System User Manual Version 2.6. UP Umweltanalytische Produkte $\mathrm{GmbH}$.

Verhoef, A., Egea, G., 2014. Modeling plant transpiration under limited soil water: Comparison ofdifferent plant and soil hydraulic parameterizations and preliminaryimplications for their use in land surface models. Agricultural and Forest Meteorology, 191, 22-32.

Vicente-Serrano, S.M., Saz-Sánchez, M.A., Cuadrat, J.M., 2011. Effects of the North Atlantic Oscillation (NAO) on combined temperature and precipitation winter modes in the Mediterranean mountains: Observed relationships and projections for the $21 \mathrm{st}$ century. Global and Planetary Change, 77, 62-76.

Villegas, J.C., Espeleta, J.E., Morrison, C.T., Breshears, D.D., Huxman, T.E., 2014. Factoring in canopy cover heterogeneity on evapotranspiration partitioning: Beyond big-leaf surface homogeneity assumptions. Journal of Soil and Water Conservation, 69, 78A-83A. DOI: 10.2489/jswc.69.3.78A

Wang, J.M., Zhuang, J.X., Wang, W.Z., Liu, S.M., Xu, Z.W., 2015. Assessment of uncertainties in eddy covariance flux measurement based on intensive flux matrix of HiWATERMUSOEXE. IEEE Geoscience and Remote Sensing Letters, 12, 2, 259-263. DOI: 10.1109/lgrs.2014.2334703

Williams, C.A., et al., 2012. Climate and vegetation controls on the surface water balance: Synthesis of evapotranspiration measured across a global network of flux towers. Water Resources Research, 48. DOI: 10.1029/2011wr011586

Williams, D.G., Cable, W., Hultine, K., Hoedjes, J.C.B., Yepez E.A., Simonneaux, V., Er-Raki, S., Boulet, G., de Bruin, H.A.R., Chehbouni, A., Hartogensis, O.K., Timouk, F., 2004. Evapotranspiration components determined by stable isotope, sap flow and eddy covariance techniques. Agricultural and Forest Meteorology, 125, 241-258. DOI: 10.1016/j.agrformet.2004.04.008

Wilson, T.G., Cortis, C., Montaldo, N., Albertson, J.D., 2014. Development and testing of a large, transportable rainfall simulator for plot-scale runoff and parameter estimation. Hydrology and Earth System Sciences, 18, 4169-4183. DOI: 10.5194/hess-18-4169-2014

Witty, J.H., Graham, R.C., Hubbert, K.R., Doolittle, J.A., Wald, J.A., 2003. Contributions of water supply from the weathered bedrock zone to forest soil quality. Geoderma, 114, 389-400. DOI: 10.1016/s0016-7601(03)00051-x

Yang, X., Crews, K.A., Yan, B., 2016. Analysis of the pattern of potential woody cover in Texas savanna. International Journal of Applied Earth Observation and Geoinformation, 52, 527-531.

Yu, K.L., D'Odorico, P., 2015. Hydraulic lift as a determinant of tree-grass coexistence on savannas. New Phytologist, 207, 1038-1051. DOI: 10.1111/nph.13431

Zhou, S., Yu, B.F., Zhang, Y., Huang, Y.F., Wang, G.Q., 2016. Partitioning evapotranspiration based on the concept of underlying water use efficiency. Water Resources Research, 52, 1160-1175. DOI: 10.1002/2015wr017766

Zwieniecki, M.A., Newton, M., 1995. Roots growing in rock fissures: Their morphological adaptation. Plant and Soil, 172, 181-187. DOI: $10.1007 /$ bf00011320

Received 17 December 2019 Accepted 6 June 2020 